\title{
A New Species of Monstrillopsis Sars, 1921 (Copepoda: Monstrilloida) with an Unusually Reduced Urosome
}

\author{
Donggu Jeon ${ }^{1}$, Wonchoel Lee ${ }^{2} \mathbb{D}$, Ho Young Soh ${ }^{3}$ and Seong-il Eyun ${ }^{1, *(D)}$ \\ 1 Department of Life Science, Chung-Ang University, 84 Heukseok-ro, Seoul 06974, Korea; \\ donggu84@gmail.com \\ 2 Department of Life Science, Hanyang University, 222 Wangsimni-ro, Seoul 04763, Korea; \\ wlee@hanyang.ac.kr \\ 3 Faculty of Marine Technology, Chonnam National University, 50 Daehak-ro, Yeosu, \\ Jeollanam-do 59626, Korea; hysoh@chonnam.ac.kr \\ * Correspondence: eyun@cau.ac.kr
}

http://zoobank.org/urn:lsid:zoobank.org:pub:36893F6D-A5D0-46C1-9D569FABBD6BF212

Received: 27 November 2019; Accepted: 18 December 2019; Published: 20 December 2019

\begin{abstract}
Male monstrilloid copepods, described herein as Monstrillopsis paradoxa sp. nov., were collected from the Chuja Islands, Jeju, Korea, using a light trap. They display many of the common features of Monstrillopsis, including large, prominent eyes, an anteriorly positioned oral papilla, and four setae on each caudal ramus. Type-2 modification of the antennules further supports the assignment of the new species to Monstrillopsis. However, the present specimens have an unusually low number of urosomal somites, just three in total, compared to five in males of all congeneric species, and from four (in Cymbasoma) to five in males of all other monstrilloid genera. Up until now, in the Monstrilloida only females of Cymbasoma have been known to have as few as three urosomal somites.

Keywords: Monstrillidae; Monstrillopsis paradoxa sp. nov.; Monstrillopsis planifrons; morphological taxonomy; tagmosis; male genitalia; pore pattern; male/female matching; marine invertebrate host; semi-parasitic; Korea
\end{abstract}

\section{Introduction}

Monstrilloida Sars, 1901 is a small group of marine copepods that comprise approximately 170 nominal species in seven genera currently considered as valid: Monstrilla Dana, 1849; Cymbasoma Thompson, 1888; Monstrillopsis Sars, 1921; Maemonstrilla Grygier \& Ohtsuka, 2008; Australomonstrillopsis Suárez-Morales \& McKinnon, 2014; Caromiobenella Jeon, Lee \& Soh, 2018; Spinomonstrilla Suárez-Morales, 2019 [1-7]. This group is distinguished from other copepods by their peculiar life cycle and strange morphology. They have a protelean life-cycle consisting of an endoparasitic juvenile phase and a planktonic adult stage. The juveniles are known to infect various marine invertebrates such as polychaetes, gastropods and bivalve mollusks [8-18]. The adults, often regarded as an exclusively reproductive stage, lack all mouth parts as well as the antennae and are non-feeding.

Most of the recent work on monstrilloids has focused on taxonomy and the morphological description of adults, but studies on the parasitic life stages and host-parasite interactions have been on the increase [2,17-19]. As well, research into monstrilloid diversity has been expanding into lesser-studied regions. For example, Suárez-Morales and McKinnon [6,20] recently described 34 species of four genera from Australian waters, with a promised treatment of similar numbers of Australian Monstrilla still to come, and such findings imply the possible occurrence of large numbers of undescribed taxa in other such areas as well. 
East Asia is clearly a region where the monstrilloid fauna has not been yet fully revealed [16,21]. Serious research on monstrilloids in Korea began less than a decade ago with the first record of Cymbasoma striifrons Chang, 2012. So far nine species in four genera have been reported from Korea's eastern and southern coastal waters [3,22-26]. The site of the present study, the Chuja Islands, is a group of 42 small islands, four of which are inhabited. They are located between Jeju Island and the mainland of Korea and are affected by the Tsushima Warm Current. Temperate and subtropical creatures coexist there $[27,28]$, leading to the expectation of high biodiversity in their surrounding waters. Here we report a new type of monstrilloid with a novel and unusual morphological feature for the group, and described it as a new species.

\section{Materials and Methods}

A plankton sample was collected by Min Ho Seo (Marine Ecology Research Center, Korea) using a hand-made polyvinyl chloride (PVC) light trap containing an light emitting diode (LED) flashlight as a light source. The type materials of the present new species were collected from 19:00 to 7:00 on 11-12 September 2017 alongside a wharf at the type locality (Figure 1). The captured contents were filtered using a $63 \mu \mathrm{m}$ mesh test sieve, and the retained material was immediately washed with $99.5 \%$ ethanol. The sample was initially fixed with $99.5 \%$ ethanol on-site and the fixative was exchanged for fresh $99.5 \%$ ethanol in the laboratory. Monstrilloids were sorted out from the bulk collection under a SMZ645 stereomicroscope (Nikon, Tokyo, Japan) and kept refrigerated at $4{ }^{\circ} \mathrm{C}$. The osmotic shock of ethanol fixation caused the cephalothorax of many specimens to collapse, so monstrilloid specimens used for morphological analysis were exposed to $0.25 \%$ trisodium phosphate dodecahydrate solution $\left(\mathrm{Na}_{3} \mathrm{PO}_{4} \cdot 12 \mathrm{H}_{2} \mathrm{O}\right.$; Daejung Chemicals and Metals, Siheung, Korea) to restore its original shape $[3,12,31]$. An Eclipse 80i compound microscope with a drawing tube and differential interference optics was used for preparing illustrations. The holotype specimen was dissected into five parts, and each was mounted on a slide separately with lactophenol for detailed examination. Body measurements were obtained by using AxioVision LE64 software (AxioVs40x64 v 4.9.1.0; Carl Zeiss, Oberkochen, Germany) based on the illustrations of the type material. Terminology from Grygier and Ohtsuka [2] and Jeon, et al. [32] was used to describe body segmentation and antennular setation patterns, respectively.
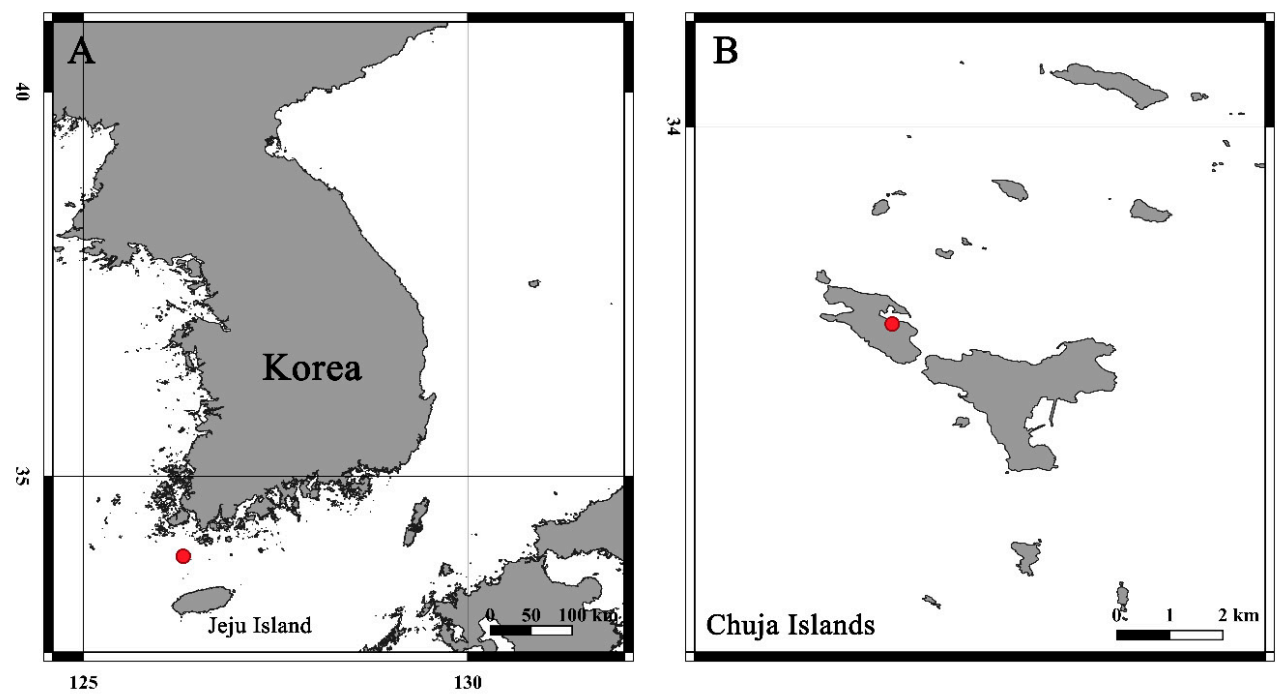

Figure 1. Maps showing the investigated area and the sampling locality. (A) Location of Chuja Islands (red dot), Korea; (B) sampling site (red dot) in Chuja Islands. The maps were prepared using QGIS [29], a free and open-source geographic information system, with the OpenStreetMap data [30]. 


\section{Results}

\subsection{Systematics}

Order Monstrilloida Sars, 1901

Family Monstrillidae Dana, 1849

Genus Monstrillopsis Sars, 1921

Monstrillopsis paradoxa sp. nov.

Figures 2-4

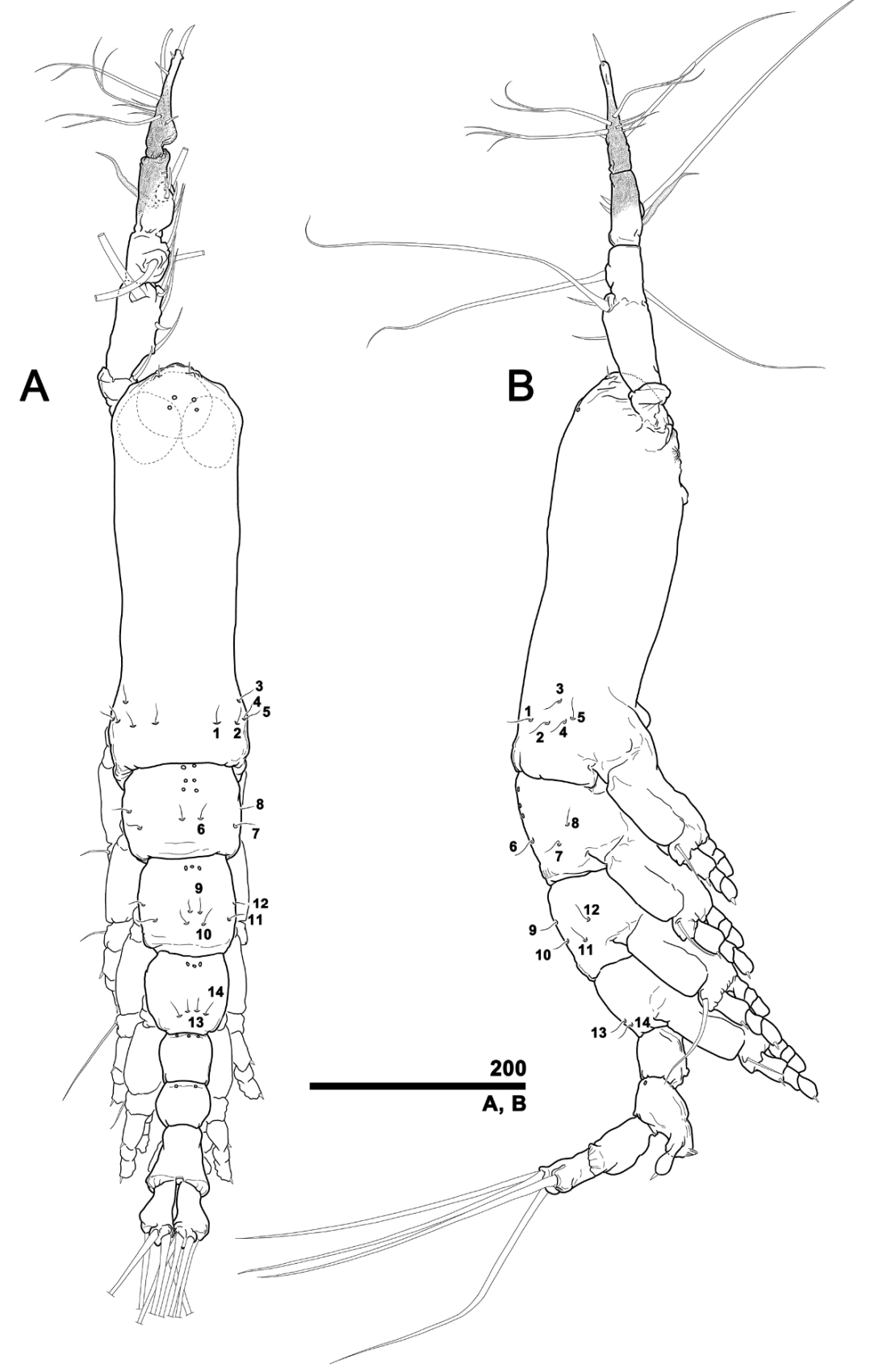

Figure 2. Monstrillopsis paradoxa sp. nov., male holotype (MABIK CR00246526) (A) Habitus with pit-setae 1-14 of right side indicated, dorsal; (B) habitus, lateral. Scale bars are in micrometers. 


\section{B}
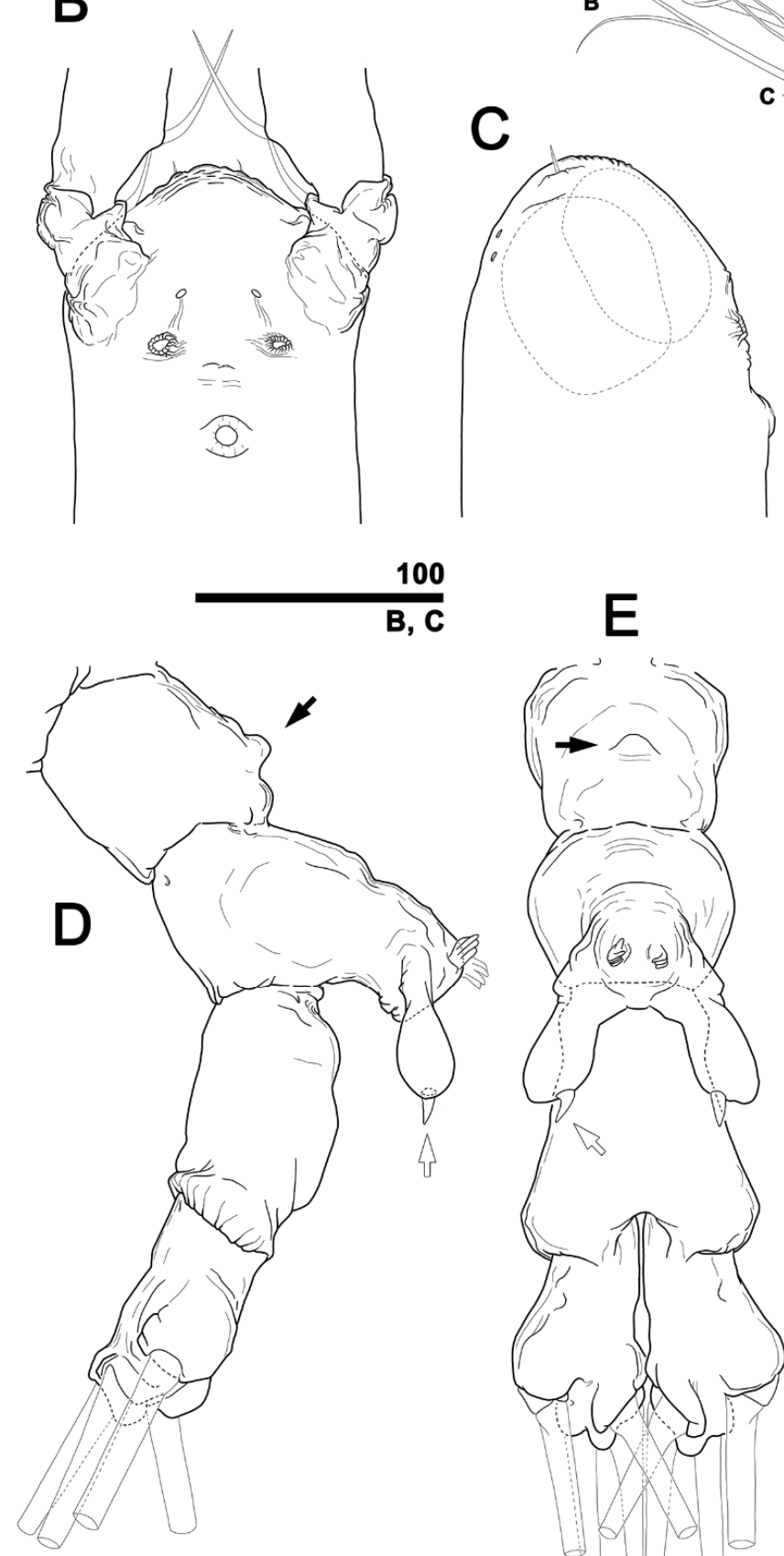

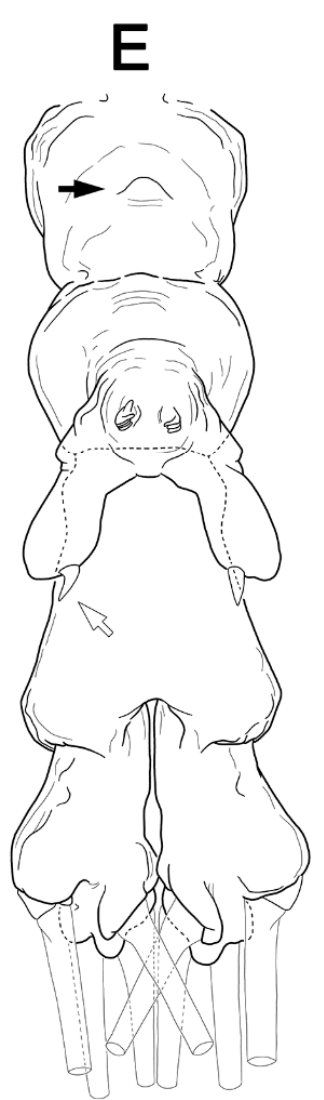

A

$5_{1}$

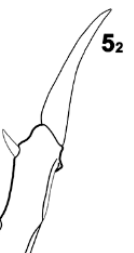

Id

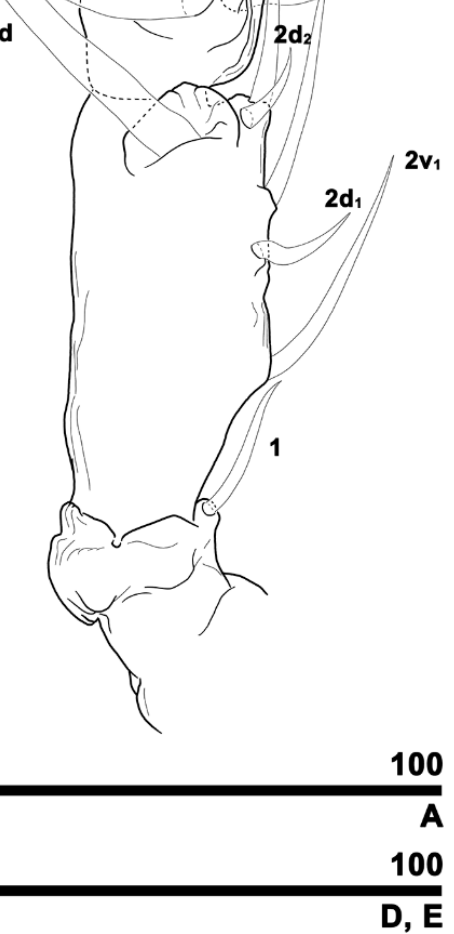

Figure 3. Monstrillopsis paradoxa sp. nov., male holotype (MABIK CR00246526). (A) Antennule, left, dorsal; (B) anterior ventral part of cephalothorax showing crumpled margin; (C) anterior part of cephalothorax, lateral; (D) urosome showing ventral protuberance (black arrow) on first urosomal somite and apical spinous element (white arrow) on genital lappet, lateral; (E) urosome showing ventral protuberance (black arrow) on the first urosomal somite and apical spinous element (white arrow) on right genital lappet. Scale bars are in micrometers. 


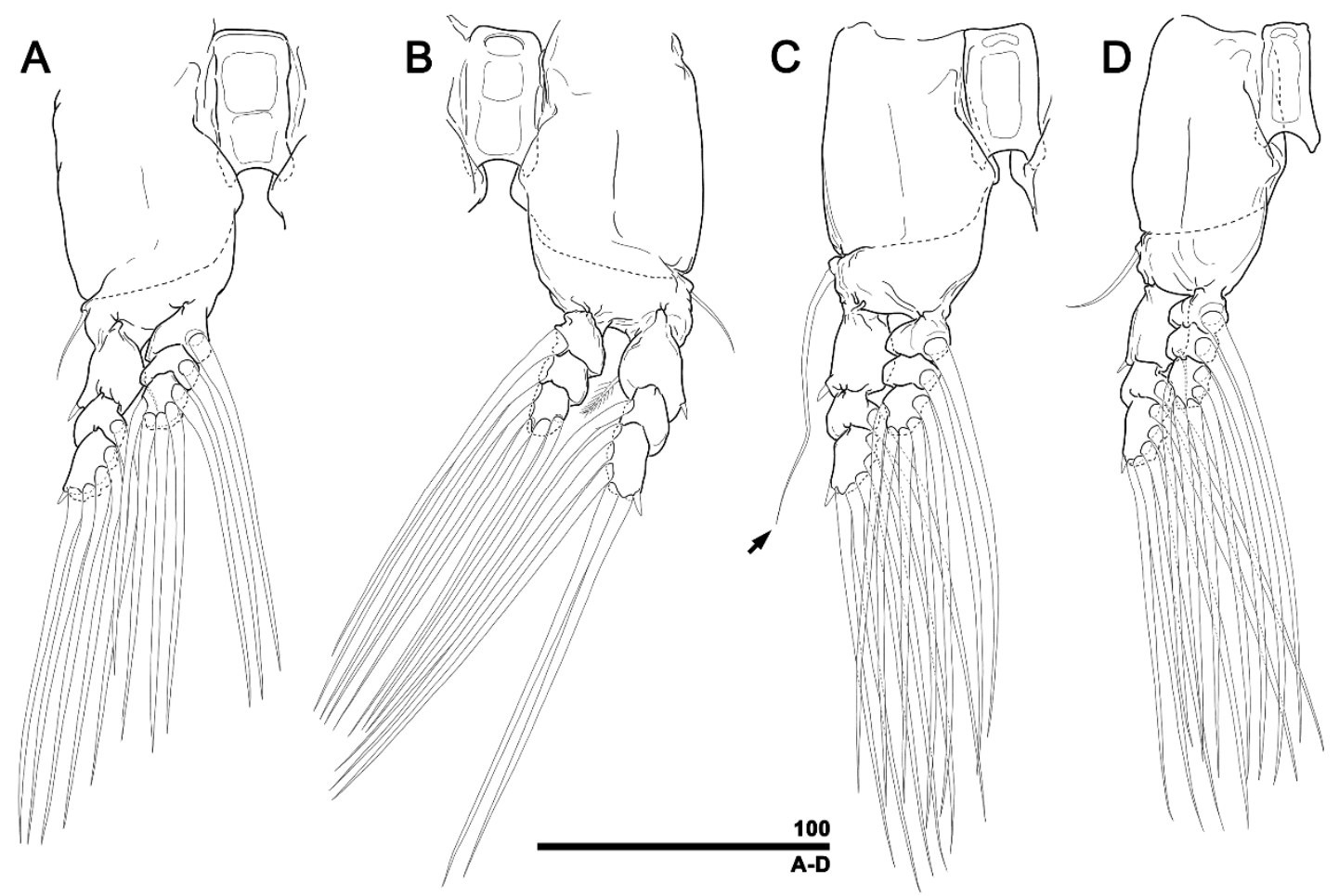

Figure 4. Monstrillopsis paradoxa sp. nov., male holotype (MABIK CR00246526). (A) Leg 1 with intercoxal sclerite, right, anterior; (B) leg 2 with intercoxal sclerite, left, anterior; (C) leg 3 showing long basal seta (arrow) and intercoxal sclerite, right, anterior; (D) leg 4 with intercoxal sclerite, left, anterior. Scale bars are in micrometers.

\subsection{Type Locality}

Yeongheung-ri (3357.59" N, 126¹7.82" E), Chuja-myeon, Jeju-si, Jeju-do, Republic of Korea. English equivalents of political divisions in Korea: ri = village; myeon = township; si = city; do $=$ province.

\subsection{Type Material Examined}

The male holotype (MABIK CR00246526; dissected and body parts mounted on five separate slides) and five intact paratypes (MABIK CR00246527; in a 99.5\% ethanol vial) are deposited in the National Marine Biodiversity Institute of Korea (MABIK), Seochon, Korea.

\subsection{Species Diagnosis. Male}

Anterior end of cephalothorax rugose with transverse striations. Antennule 5-segmented with geniculation between fourth and fifth segments. Fifth segment showing type-2 modification [13]: inner proximal one-third with hyaline bump, rest of distal part thin, elongate. Two distal segments dark brown in ethanol-preserved specimens (coloration becoming fainter with time, and immediate partial bleaching occurring upon exposure to $\mathrm{Na}_{3} \mathrm{PO}_{4}$ solution and/or lactophenol): outer lateral side of the fourth segment most strongly pigmented; the fifth segment with gradual distal weakening of pigmentation, completely lacking pigment near the tip. Outermost natatory seta on the third exopodal segment of all legs smooth, lacking typical serration along its outer side. Outer basal seta on third legs extremely long, well exceeding its exopod. Anterior dorsum of first free pediger with three pairs of pores arrayed in two rows flanking midline. Succeeding three somites, i.e. second and third free pedigers and first urosomal somite, each with a transverse row of three pores near the anterior dorsal margin, with middle pore on midline. Urosome consisting of three somites, viz., limbless fourth 
free pediger (= first urosomal somite) and genital somite followed directly by anal somite, with no post-genital or penultimate (= preanal) somites. First urosomal somite lacking fifth legs, but with small posterioventral protuberance instead. Genital somite with ventral genital apparatus consisting of a shaft and two lappets. Shaft robust with abrupt notch at midlength in lateral view, more distal part slightly thinner than proximal part and bearing two hand-shaped opercular flaps anteriorly at tip. Genital lappets diverging from posterior distal part of the shaft, clavate in lateral view, rather lamelliform in ventral view. Each lappet armed with a short, robust spinous element at the inner distal corner. Caudal rami twice as long as wide, each with four seate. All caudal setae subequal in length, with inner ventral seta almost always extending diagonally downwards. Measurements: total body length ranged from $0.66-0.88 \mathrm{~mm}$ (mean $0.78 \mathrm{~mm} ; N=6$ for all measurements reported here). Length ratio (means, with ranges in parentheses) of cephalothorax, metasome, and urosome 49.0 (46.6-53.2):34.1 (30.2-36.6):16.9 (15.9-19.6) in lateral view. Oral papilla located 25.9\% (24.3-27.4\%) back along the ventral side of cephalothorax. Length of antennules in relation to total body length $45.1 \%$ (42.1-51.0\%), and to length of cephalothorax 91.9\% (86.0-97.0\%). Ratio of antennular segment length from proximal to distal 12.3 (11.8-13.8):23.8 (21.7-26.6):14.2 (11.9-16.3):19.9 (19.4-20.4):29.8 (28.9-30.4).

\subsection{Description of Male Holotype (MABIK CR00246526)}

Total body length $0.76 \mathrm{~mm}$ in dorsal view, $0.78 \mathrm{~mm}$ in lateral view (Figure 2A,B). Body consisting of cephalothorax incorporating first pediger, free somites 1-3, first urosomal somite, genital somite, and anal somite. Length of somites as percent of total body length 49:12:12:9:6:5:7 in dorsal view, 49:14:12:9:5:4:7 in lateral view. Cephalothorax cylindrical, $0.37 \mathrm{~mm}$ long in dorsal view, $0.38 \mathrm{~mm}$ long in lateral view, accounting for almost half of total body length. Anterior margin convex, its surface corrugated with strong transversal striations. Anterior part of the forehead with two short, thin sensilla. Width of cephalothorax almost unvarying along its length: narrowest (= waist width; $0.11 \mathrm{~mm}$ ) at $76.5 \%$, widest (= incorporated first pediger; $0.13 \mathrm{~mm}$ ) at $91.9 \%$ of distance from anterior end. Anterior one-fourth nearly fully occupied by one ventral and two lateral eyes (Figure 2A, Figure 3C). Ventral eye located more anteriorly than lateral eyes, with 1.29 times greater diameter than the latter $(70.3 \mu \mathrm{m}$ versus $54.5 \mu \mathrm{m})$. Dorsal surface at the level of eyes with at least four pores in the trapezoidal array (Figure 2A). Ventral surface at the same level with pair of pores and pair of scars (Figure 3B); pores located medially between antennular bases, and scars slightly behind of antennular bases but still medial to them. Moderately developed oral papilla located behind scars, $26 \%$ back from anterior margin of cephalothorax. Tergite of incorporated first pediger with five pairs of pit-setae sensu Grygier and Ohtsuka [19]: one pair (no. 1) situated dorsally, four pairs laterally (nos. 2-5).

Body somites from first pedigerous somite to genital somite with several pores in various places (Figure 2A,B). First free pediger with three pairs of pit-setae posteriorly (nos. 6-8: one pair dorsally, two pairs laterally) and two longitudinal rows of four pores each, arranged in pairs across midline, with most anterior pore pair covered by posterior cuticular extension of cephalothorax. Second free pediger with four pairs of pit-setae posteriorly (nos. 9-12: two pairs dorsally, two pairs laterally) and three simple pores aligned transversally across anterior midline. Third free pediger with two pairs of pit-setae posteriorly (nos. 13,14), aligned transversely across dorsum, and transverse row of three simple pores on anterior dorsum. The first urosomal somite also with three simple pores on anterior dorsum and with protuberance near the posterior end of the ventral side. Genital somite with a pair of simple pores in anterior dorsum.

Antennules 5-segmented, with geniculation between fourth and fifth segments (Figure 3A). Length $0.35 \mathrm{~mm}$ excluding apical spine $5_{2}$, equal to $44.1 \%$ of total body length, $90.2 \%$ of cephalothorax length. Length ratio of segments 12:26:12:20:30. First antennular segment with spinous element 1 on inner distal corner, arising slightly dorsally. Second segment armed with five spinous elements $\left(2 \mathrm{v}_{1-3}, 2 \mathrm{~d}_{1,2}\right)$ plus long, strap-like, biplumose seta IId. Ventral spinous elements (2v-series) well developed, slightly longer than dorsal ones (2d-series). Third segment with three elements ( 3 , IIId, IIIv); spinous element 3 located distally on inner side, long IIIv and IIId setae extending ventrally and 
dorsally, respectively, from midlength of segment. Fourth segment with eight elements $\left(4 \mathrm{v}_{1-3}, 4 \mathrm{~d}_{1,2}\right.$, $4 \mathrm{a}, \mathrm{IVv}$, 4aes): naked spinous element $4 \mathrm{v}_{1}$ thin, twice as long as other $4 \mathrm{~d}-, 4 \mathrm{v}$-elements; four spinous elements $4 \mathrm{v}_{2,3}$ and $4 \mathrm{~d}_{1,2}$ all robust, pinnate, curved toward bearing segment; spinous element $4 \mathrm{a}$ minute, arising at inner distal one-third of segment; IVv and 4aes arising from ventral surface of segment, 4aes more proximally. Fifth antennular segment modified: inner proximal margin with semicircular expansion, rest of distal part relatively thin, elongate, and twice as long as proximal expansion (Figure 3A). Inner side of distal elongated part with thin, film-like hyaline edge. Segment armed with 12 setal elements. Among these, spinous element $5_{1}$ short, located on outer distal margin; apical spinous element $5_{2}$ elongate, $26 \%$ as long as bearing segment; inner spinous element $5_{3}$ arising from dorsal distal part of inner expansion; minute spinous element 5 a arising from proximal part of expansion; and long, strap-like seta $V_{v}$ arising from ventral surface at level of spinous element $5_{3}$. Six outer setae present at midlength of fifth segment: four branched setae (A-D) and two short, simple setae $(a, b)$. Branched seta $C$ rather simple, significantly shorter than other branched setae but still longer than two simple setae. Aesthetasc (5aes) located on the outer side of the segment's distal quarter, longer than spine $5_{1}$. Fourth antennular segment dark brown, especially prominent along the outer lateral side. Proximal half of fifth segment except for hyaline expansion also dark, but pigmentation fading distally, completely absent at tip.

Genital somite rounded in dorsal view, with robust genital shaft constricted at midlength so as to appear notched in lateral view (Figure 2A,Figure 3D,E). Distal part armed with two hand-shaped opercular flaps. Pair of genital lappets diverging from posterior distal part of the shaft, clavate in lateral view, relatively flat and wide in ventral view (Figure 3D,E). Each lappet armed with a short spinous element at the inner distal corner (Figure 3D,E).

Caudal rami (Figure 3D,E) diverging from posterior margin of anal somite, 1.8 times longer than wide. Each ramus armed with four setae: one outer lateral, two dorsal apical, one inner ventral. All caudal setae biplumose, subequal in length.

Incorporated first pediger and three succeeding free pedigers each with pair of well-developed swimming legs (Figure 4A-D). Protopods consisting of a large coxal portion and a relatively small basis. Anterior articulation between coxa and basis poorly defined whereas posterior diagonal articulation clearly expressed. Coxae of each leg pair joined by longitudinally elongate, rectangular intercoxal sclerite 1.9 times longer than wide. Basis of legs 1, 2 and 4 with short seta proximally on outer margin, reaching at most to middle of first exopodal segment; on leg 3 this seta coarsely plumose and distinctly longer, extending well beyond the tip of exopod. Basis with tri-articulate endopod and exopod on distal margin, with endopod positioned more anteriorly than exopod and reaching only to the distal end of the second exopodal segment. First and third exopodal segments 2 times longer than the second segment, but all three endopodal segments subequal in length. Setal patterns of legs 1-4 are shown in Table 1.

Table 1. Setal armature patterns of legs $1-4$.

\begin{tabular}{ccccc}
\hline & Coxa & Basis & Exopod & Endopod \\
\hline Leg 1 & $0-0$ & $1-0$ & $\mathrm{I}-1 ; 0-1 ; \mathrm{I}, 2,2$ & $0-1 ; 0-1 ; 1,2,2$ \\
Legs $2-4$ & $0-0$ & $1-0$ & $\mathrm{I}-1 ; 0-1 ; \mathrm{I}, 2,3$ & $0-1 ; 0-1 ; 1,2,2$ \\
\hline
\end{tabular}

Roman numerals indicate the number of spines, Arabic numerals indicate number of seate.

Outermost setae of third exopodal segments of all legs smooth, with no serration along outer side. Natatory setae subequally long except short inner setae on first exopodal segment not extending beyond tip if endopod. Fifth legs absent.

\subsection{Females}

Unrecognized. 


\subsection{Remarks}

The present males are assignable to Monstrillopsis by virtue of the presence of type- 2 male antennular modification with the fifth segment modified into a gradually tapering, elongate distal half with a slightly inner curved spine on the tip and a hyaline expansion on the inner proximal margin [12,21]. This kind of modification is shared with seven congeners, including M. sarsi Isaac, 1974, M. dubioides Suárez-Morales, 2004 [4] (for male), M. chilensis Suárez-Morales, Bello-Smith \& Palma, 2006 [33] (for male), M. boonwurrungorum Suárez-Morales \& McKinnon, 2014 [34] (correct original spelling), M. hastata Suárez-Morales \& McKinnon, 2014, M. nanus Suárez-Morales \& McKinnon, 2014, and M. pontoeuxinensis Suárez-Morales \& Üstün, 2018. Males of six other congeners, $M$. reticulata (Davis, 1949), M. fosshageni Suárez-Morales \& Dias, 2001, M. chathamensis Suárez-Morales \& Morales-Ramírez, 2009, M. cahuitae Suárez-Morales \& Carrillo, 2013, M. coreensis Lee, Kim \& Chang, 2016 and M. longilobata Lee, Kim \& Chang 2016 have a much less elongate distal portion of the fifth segment, with a rather long and robust apical spinous element $5_{2}$. Four species of the former group, $M$. dubioides, $M$. sarsi, $M$. nanus, and M. pontoeuxinensis can be immediately excluded from further morphological consideration because of significant differences in body size compared to M. paradoxa sp. nov., either larger (2.1 mm for $M$. dubioides, $1.2 \mathrm{~mm}$ for $M$. sarsi) or smaller ( $0.5 \mathrm{~mm}$ for M. nanus and $0.6 \mathrm{~mm}$ for M. pontoeuxinensis) $[4,6,35,36]$.

Suárez-Morales and McKinnon [6] recognized mainly two types of male genitalia in Monstrillopsis: type I with a strong, well-developed median shaft and relatively short, rounded lappets, and type II with a relatively short median shaft and very elongate lappets arising from the posterolateral corners. The latter is characteristic of all three congeners with type- 2 male antennules that were not excluded above on account of body size. These have long, slender, cylindrical lappets $[6,26,33]$, however, while the genital lappets of the new species appear lamellar in the ventral view. In addition, the lappets of M. paradoxa sp. nov. are armed with a very short but robust inner distal spinous element, something not previously reported in males of any species of Monstrillopsis. The most stunning morphological character of the present males is the unusually low number of somites in the urosome. Up to now, both sexes of Cymbasoma have been known to have the fewest urosomal somites among the known monstrilloid genera-females with three, including post-genital somite, and males with four, including post-genital and penultimate somites [8,20,21]. Males of the present new species have one fewer somite than males of Cymbasoma while matching the number in females of Cymbasoma. Despite this disparity compared to other species of Monstrillopsis, which have five urosomal somites in general, nevertheless, we have assigned the present males to Monstrillopsis in consideration of its possession of several other Monstrillopsis-like features: large, prominent eyes, an anteriorly-located oral papilla, and four caudal setae (see Discussion).

\subsection{Etymology}

The specific epithet is derived from the Latin adjective paradoxus, - - , - um (adopted from the Greek paradoxos), meaning strange, with a feminine ending to match the gender of the genus name. It pertains to the contradictory morphological characteristics, a type-2 antennular modification supporting placement in Monstrillopsis, and an unusually low number of body somites, which argues against such placement.

\section{Discussion}

The number of body somites has been considered one of the most important, convenient, and evident key features in the monstrilloid taxonomy [4,7,8,37]. The species of Cymbasoma, for instance, have been distinguished from the other monstrilloid genera based almost on this criterion alone [38-40]. A review of the most recent 20 years of taxonomic works dealing with over 40 species of Cymbasoma (more than half of the total species recorded in this genus) shows that authors continue to use this feature as the primary feature for generic assignment [20,22,41-46]. In light of this history, the even 
lower number of urosomal somites in the present specimens may provide grounds for proposing a new genus of Monstrilloida. On the other hand, the new species presents a typical type-2 antennular modification, which may be just as important. Full expression of this feature is shared by more than half of the hitherto known males of Monstrillopsis, and including partial expression, it has been regarded as a diagnostic feature for the genus [12,47]. Therefore, antennular morphology unambiguously suggests a close morphological affinity of the present specimens to Monstrillopsis, and the presence of other Monstrillopsis-like characteristics in them further supports their assignment to this genus.

The cuticular pore pattern described above for Monstrillopsis paradoxa sp. nov. can be compared with that reported from female M. planifrons Delaforge, Suárez-Morales, Walkusz, Campbell \& Mundy, 2017. Unlike any other congeneric species, this species has three pairs of dorsal structures, described as "minute papilla-like processes" [48] (p. 4), flanking the midline of the first free pediger. The present new species has six pores arrayed the same way on this somite. Perhaps the structures in M. planifrons were also sort of pores. Be this as it may, it is worth noting that Grygier and Ohtsuka [2] have already considered the potential utility of cuticular ornamentation patterns for differentiation and identification. Based on a limited number of examples, they found a stereotypical pore pattern among monstrilloids that distinguishes them from other copepod groups. In addition, based on detailed SEM photographs of four species of Maemonstrilla, Grygier and Ohtsuka showed that these species share a similar pore arrangement on the second free pediger [2] (fig. 29). The species of Caromiobenella provide another example in that they share a set of four pairs of pores flanking the midline along the posterior medio-dorsal part of the cephalothorax $[3,19,23,24]$. The currently available evidence thus suggests that pore pattern may be useful in identifying monstrilloids at the genus-level; if so, the present new species still falls into Monstrillopsis.

A distinctive pore pattern shared between individuals of different sexes can occasionally reveal their conspecificity. The presence of a similar pore pattern in certain males and females was taken as evidence that both belonged to Monstrillopsis longilobata, and this was corroborated by molecular analysis [32]. With this example in mind, the possibility that M. planifrons and M. paradoxa sp. nov. are the females and males, respectively, of one species must be considered. We think it unlikely, on account of substantial differences in other morphological details besides the dorsal ornamentation of the first free pediger. In particular, unlike males of M. paradoxa sp. nov., females of M. planifrons are characterized in having (1) a produced, flat, corrugated forehead and (2) a cephalothorax entirely covered in numerous minute papillae, that are considered as species-specific features [48]. None of those features is presented in the present male specimens: the present males have a rounded, convex forehead with transverse striae. The whole cephalothorax is smooth without additional ornamental structures. The outermost seta of the third exopodal segment of legs 1-4 is also different in each species. This seta is, in general, with an inner row of setules and an outer row of coarse spinules as so in M. planifrons. The seta of all legs in the present new species is, however, presented without the outer serration. The significant size difference in body length ( $1.92 \mathrm{~mm}$ for the female holotype of $M$. planifrons versus a range of $0.66-0.88 \mathrm{~mm}$ for the present males) and considerations of biogeography and habitat $M$. planifrons being from the Canadian Arctic and M. paradoxa sp. nov. from warm-temperate or subtropical waters in East Asia-mitigate against conspecificity [48]. On the other hand, the characteristics mentioned above of the present males may be useful as morphological markers for finding the currently unknown female counterparts. The distinct pigmentation pattern exhibited on the distal part of the antennules in the present males might also be expected to appear in the unknown females.

Female monstrilloids usually have one fewer urosomal somite than the corresponding males $[4,8,12,21]$. In this rule holds for $M$. paradoxa sp. nov., the unknown females should have a urosome consisting of just two somites: either the first urosomal somite (= fourth free pediger) and the genital (compound) somite, or the genital (compound) somite and anal somite. Loss of the genital somite with retention of the other two would not be supportable, but from a functional point of view, none of these options seems likely. Therefore, we presume that the females of M. paradoxa sp. nov. will prove to have at least three somites in their urosome. If so, they will be similar to females of Cymbasoma 
in terms of the body plan, but distinguishable by the number of caudal setae. Most female Cymbasoma have three caudal setae $[20,21]$, and the number of caudal setae is the same (four) in both sexes of those species of Monstrillopsis [47].

Our discovery of a new body plan in specimens of the greatly modified, but nonetheless highly stereotyped group Monstrilloida is a sign that further collection and detailed examination of these copepods will continue to turn up surprises. The difficulty in classifying the new species also shows that a phylogenetic systematic approach to monstrilloid taxonomy is overdue. We hope to make progress on this in upcoming works.

Author Contributions: Conceptualization, D.J., W.L., H.Y.S. and S.-i.E.; Data curation, D.J., W.L., H.Y.S. and S.-i.E.; formal analysis, D.J., W.L., H.Y.S. and S.-i.E.; funding acquisition, D.J. and S.-i.E.; investigation, D.J.; methodology, D.J.; project administration, D.J., W.L., H.Y.S. and S.-i.E.; resources, D.J., W.L., H.Y.S. and S.-i.E.; supervision, W.L., H.Y.S. and S.-i.E.; validation, D.J., W.L., H.Y.S. and S.-i.E.; visualization, D.J.; writing—original draft, D.J.; writing-review and editing, D.J., W.L., H.Y.S. and S.-i.E. All authors have read and agreed to the published version of the manuscript.

Funding: This study was supported by Basic Science Research Program through the National Research Foundation of Korea (NRF) funded by the Ministry of Education (MOE) (grant no. 2019R1I1A1A01057892) and the Chung-Ang University Research Grants in 2018.

Acknowledgments: We are grateful to Mark J. Grygier (Center for Excellence for the Oceans, National Taiwan Ocean University, Taiwan) for providing his kind English correction and valuable comments to improve the overall quality of the manuscript. We also appreciate the three anonymous reviewers and the editors for providing their helpful comments and advice.

Conflicts of Interest: The authors declare no conflict of interest.

\section{References}

1. Dana, J.D. Conspectus Crustaceorum quae in Orbis Terrarum circumnavigatione, Carolo Wilkes e Classe Reipublicae Faederatae Duce, lexit et descripsit Jacobus, D. Dana. Pars II. Proc. Am. Acad. Arts Sci. 1849, 2, 9-61.

2. Grygier, M.J.; Ohtsuka, S. A new genus of monstrilloid copepods (Crustacea) with anteriorly pointing ovigerous spines and related adaptations for subthoracic brooding. Zool. J. Linn. Soc. 2008, 152, 459-506. [CrossRef]

3. Jeon, D.; Lee, W.; Soh, H.Y. A new genus and two new species of monstrilloid copepods (Copepoda: Monstrillidae): Integrating morphological, molecular phylogenetic, and ecological evidence. J. Crustacean Biol. 2018, 38, 45-65. [CrossRef]

4. Sars, G.O. An account of the Crustacea of Norway with short descriptions and figures of all the species. In Copepoda Monstrilloida \& Notodelphyoida; The Bergen Museum: Bergen, NJ, USA, 1921; Volume III, p. 91.

5. Suárez-Morales, E. A new genus of the Monstrilloida (Copepoda) with large rostral process and metasomal spines, and redescription of Monstrilla spinosa Park, 1967. Crustaceana 2019, 92, 1099-1112. [CrossRef]

6. Suárez-Morales, E.; McKinnon, A.D. The Australian Monstrilloida (Crustacea: Copepoda) I. Monstrillopsis Sars, Maemonstrilla Grygier \& Ohtsuka, and Australomonstrillopsis gen. nov. Zootaxa 2014, 3779, 301-340.

7. Thompson, I.C. Copepoda of Madeira and the Canary Islands, with descriptions of new genera and species. J. Linn. Soc. Lond. Zool. 1888, 20, 145-156. [CrossRef]

8. Boxshall, G.A.; Halsey, S.H. An Introduction to Copepod Diversity; The Ray Society: London, UK, $2004 ;$ p. 966.

9. Caullery, M.; Mesnil, F. Sur deux Monstrillides parasites d'Annélides (Polydora giardi Mesn. et Syllis gracilis Gr.). Bull. Sci. Fr. Bel. 1914, 48, 15-29.

10. Gallien, L. Description du mâle de Monstrilla helgolandica Claus. Synonymie de Monstrilla serricornis G. O. Sars et de Monstrilla helgolandica Claus. Bull. Soc. Zool. Fr. 1934, 59, 377-382.

11. Hartman, O. A new monstrilloid copepod parasitic in capitellid polychaetes in Southern California. Zool. Anz. 1961, 167, 325-334.

12. Huys, R.; Boxshall, G. Copepod Evolution; The Ray Society: London, UK, 1991; p. 468.

13. Huys, R.; Llewellyn-Hughes, J.; Conroy-Dalton, S.; Olson, P.D.; Spinks, J.N.; Johnston, D.A. Extraordinary host switching in siphonostomatoid copepods and the demise of the Monstrilloida: Integrating molecular data, ontogeny and antennulary morphology. Mol. Phylogenet. Evol. 2007, 43, 368-378. [CrossRef] 
14. Malaquin, A. Le parasitisme évolutif des Monstrillides (Crustacés Copépodes). Arch. Zool. Exp. Gén. 1901, 9, 81-232.

15. Pelseneer, P. Éthologie de quelques Odostomia et d'un Monstrillide parasite de l'un d'eux. Bull. Sci. Fr. Bel. 1914, 48, 1-14.

16. Suárez-Morales, E. Monstrilloid copepods: The best of three worlds. Bull. South. Calif. Acad. Sci. 2018, 117, 92-103. [CrossRef]

17. Suárez-Morales, E.; Harris, L.H.; Ferrari, F.D.; Gasca, R. Late postnaupliar development of Monstrilla sp. (Copepoda: Monstrilloida), a protelean endoparasite of benthic polychaetes. Invertebr. Reprod. Dev. 2014, 58, 60-73. [CrossRef]

18. Suárez-Morales, E.; Paiva Scardua, M.; Da Silva, P.M. Occurrence and histopathological effects of Monstrilla sp. (Copepoda: Monstrilloida) and other parasites in the brown mussel Perna perna from Brazil. J. Mar. Biol. Assoc. UK 2010, 90, 953-958. [CrossRef]

19. Grygier, M.J.; Ohtsuka, S. SEM observation of the nauplius of Monstrilla hamatapex, new species, from Japan and an example of upgraded descriptive standards for monstrilloid copepods. J. Crustacean Biol. 1995, 15, 703-719. [CrossRef]

20. Suárez-Morales, E.; McKinnon, A.D. The Australian Monstrilloida (Crustacea: Copepoda) II. Cymbasoma Thompson, 1888. Zootaxa 2016, 4102, 1-129.

21. Suárez-Morales, E. Diversity of the Monstrilloida (Crustacea: Copepoda). PLoS ONE 2011, 6, e22915. [CrossRef]

22. Chang, C.Y. First record of Monstrilloid copepods in Korea: Description of a new species of the genus Cymbasoma (Monstrilloida, Monstrillidae). Anim. Syst. Evol. Divers. 2012, 28, 126-132. [CrossRef]

23. Chang, C.Y. Two new records of monstrilloid copepods (Crustacea) from Korea. Anim. Syst. Evol. Divers. 2014, 30, 206-214. [CrossRef]

24. Jeon, D.; Lee, W.; Soh, H.Y. New species of Caromiobenella Jeon, Lee \& Soh, 2018 (Crustacea, Copepoda, Monstrilloida) from Chuja Island, Korea. ZooKeys 2019, 814, 33-51.

25. Lee, J.; Chang, C.Y. A new species of Monstrilla Dana, 1849 (Copepoda: Monstrilloida: Monstrillidae) from Korea, including a key to species from the north-west Pacific. Zootaxa 2016, 4174, 396-409. [CrossRef] [PubMed]

26. Lee, J.; Kim, D.; Chang, C.Y. Two new species of the genus Monstrillopsis Sars, 1921 (Copepoda: Monstrilloida: Monstrillidae) from South Korea. Zootaxa 2016, 4174, 410-423. [CrossRef] [PubMed]

27. Cho, I.-Y.; Kang, D.-W.; Kang, J.; Hwang, H.; Won, J.-H.; Paek, W.K.; Seo, S.-Y. A study on the biodiversity of benthic invertebrates in the waters of Seogwipo, Jeju Island, Korea. J. Asia Pac. Biodivers. 2014, 7, e11-e18. [CrossRef]

28. Yang, H.J.; Seo, J.E.; Gordon, D.P. Sixteen new generic records of Korean Bryozoa from southern coastal waters and Jeju Island, East China Sea: Evidence of tropical affinities. Zootaxa 2018, 4422, 493-518. [CrossRef]

29. Van Cleave, H.J.; Ross, J.A. A method for reclaiming dried zoological specimens. Science 1947, 105, 318. [CrossRef]

30. QGIS. A Free and Open Source Geographic Information Systam. Available online: https://qgis.org (accessed on 20 December 2019).

31. Data Derived from OpenStreetMap for Download. Available online: https://osmdata.openstreetmap.de/ (accessed on 20 December 2019).

32. Jeon, D.; Lim, D.; Lee, W.; Soh, H.Y. First use of molecular evidence to match sexes in the Monstrilloida (Crustacea: Copepoda), and taxonomic implications of the newly recognized and described, partly Maemonstrilla-like females of Monstrillopsis longilobata Lee, Kim \& Chang, 2016. PeerJ 2018, 6, e4938.

33. Suárez-Morales, E.; Ramírez, F.C.; Derisio, C. Monstrilloida (Crustacea: Copepoda) from the Beagle Channel, South America. Contrib. Zool. 2008, 77, 217-226. [CrossRef]

34. Grygier, M.J.; Suárez-Morales, E. Recognition and partial solution of nomenclatural issues involving copepods of the family Monstrillidae (Crustacea: Copepoda: Monstrilloida). Zootaxa 2018, 4486, 497-509. [CrossRef]

35. Isaac, M.J. Copepoda Monstrilloida from south-west Britain including six new species. J. Mar. Biol. Assoc. UK 1974, 54, 127-140. [CrossRef]

36. Suárez-Morales, E.; Üstün, F. Report on some monstrilloids (Crustacea: Copepoda) from Turkey with description of two new species. Cah. Biol. Mar. 2018, 59, 547-562. 
37. Giesbrecht, W. Systematik und Faunistik der pelagischen Copepoden des Golfes von Neapel und der angrenzenden Meeres-Abschnitte. Fauna und Flora des Golfes von Neapel und der angrenzenden Meeres-Abschnitte herausgegeben von der Zoologischen Station zu Neapel. XIX. Monographie; Verlag von R. Friedländer \& Sohn: Berlin, Germany, 1892; p. 831.

38. Mageed, A.A.A. Cymbasoma janetae n. sp., a new monstrilloid (Copepoda, Monstrilloida) from the Gulf of Aqaba (Red Sea, Egypt). Crustaceana 2010, 83, 513-523. [CrossRef]

39. Suárez-Morales, E. A new species of Cymbasoma (Copepoda: Monstrilloida) from the Mediterranean Sea with remarks on the female of C. tumorifrons (Isaac). Mitt. Mus. Nat. Berl. Zool. Reihe 2002, 78, 87-96. [CrossRef]

40. Suárez-Morales, E.; Morales-Ramírez, A. A new species of Cymbasoma (Crustacea: Copepoda: Monstrilloida) from the Pacific coast of Costa Rica, Central America. Proc. Biol. Soc. Wash. 2003, 116, 206-214.

41. Lian, X.; Tan, Y. A new species of Cymbasoma Thompson, 1888 (Copepoda: Monstrilloida) from the Fujian coast, China. J. Oceanol. Limnol. 2019, 37, 1709-1713. [CrossRef]

42. Suárez-Morales, E.; Carrillo, A.; Morales-Ramírez, A. Report on some monstrilloids (Crustacea: Copepoda) from a reef area off the Caribbean coast of Costa Rica, Central America with description of two new species. J. Nat. His. 2013, 47, 619-638. [CrossRef]

43. Suárez-Morales, E.; Dias, C.d.O. Taxonomic report of some monstrilloids (Copepoda: Monstrilloida) from Brazil with description of four new species. Bull. Inst. R. Sci. Nat. Belg. Biol. 2001, 7, 65-81.

44. Suárez-Morales, E.; Goruppi, A.; de Olazabal, A.; Tirelli, V. Monstrilloids (Crustacea: Copepoda) from the Mediterranean Sea (Northern Adriatic Sea), with a description of six new species. J. Nat. Hist. 2017, 51, 1795-1834. [CrossRef]

45. Suárez-Morales, E.; Morales-Ramírez, A. New species of Monstrilloida (Crustacea: Copepoda) from the Eastern Tropical Pacific. J. Nat. Hist. 2009, 43, 1257-1271. [CrossRef]

46. Suárez-Morales, E.; Pilz, D. A new species of Cymbasoma (Copepoda: Monstrilloida) from Florida with a redecription of C. quadridens. J. Mar. Biol. Assoc. UK 2008, 88, 527-533. [CrossRef]

47. Suárez-Morales, E.; Bello-Smith, A.; Palma, S. A revision of the genus Monstrillopsis Sars (Crustacea: Copepoda: Monstrilloida) with description of a new species from Chile. Zool. Anz. 2006, 245, 95-107. [CrossRef]

48. Delaforge, A.; Suárez-Morales, E.; Walkusz, W.; Campbell, K.; Mundy, C.J. A new species of Monstrillopsis (Crustacea, Copepoda, Monstrilloida) from the lower Northwest Passage of the Canadian Arctic. Zookeys 2017, 709, 1-16. [CrossRef] [PubMed]

(C) 2019 by the authors. Licensee MDPI, Basel, Switzerland. This article is an open access article distributed under the terms and conditions of the Creative Commons Attribution (CC BY) license (http://creativecommons.org/licenses/by/4.0/). 